\title{
Describing Complexity in Palliative Home Care Through HexCom: A Cross-Sectional, Multicenter Study
}

This article was published in the following Dove Press journal:

Journal of Multidisciplinary Healthcare

Xavier Busquet-Duran (1D ${ }^{1-3}$

Eva Maria Jiménez-Zafra'

Josep Maria Manresa-

Domínguez $\mathbb{D}^{2,4,5}$

Magda Tura-Poma'

Olga Bosch-delaRosa ${ }^{6}$

Anna Moragas-Roca'

Maria Concepción Galera

Padilla'

Susana Martin Moreno (D'

Emilio Martínez-Losada'

Silvia Crespo-Ramírez ${ }^{6}$

Ana Isabel López-Garcia'

Pere Torán-Monserrat $\mathbb{D}^{2,4}$

'Home Care Program, Support Team, PADES Granollers, Vallès Oriental Primary Health Care Services, Catalan Institute of Health, Barcelona, Spain;

${ }^{2}$ Multidisciplinary Research Group on

Health and Society (GREMSAS),

Barcelona, Spain; ${ }^{3}$ Department of Nursing, University Foundation of Bages (FUB), University of Vic. Central University of Catalunya, Barcelona, Spain; ${ }^{4}$ Metropolitan Nord Unit of Research Support, University Institute of Research in Primary Care (IDIAP) Jordi Gol, Barcelona, Spain; ${ }^{5}$ Department of Nursing, Autonomous University of Barcelona, Barcelona, Spain;

${ }^{6}$ Psychosocial Care Team (EAPS), Red

Cross, Granollers, Barcelona, Spain

Correspondence: Xavier Busquet-Duran Email xbusquet@umanresa.cat
Background: Complexity has become a core issue in caring for patients with advanced disease and/or at the end-of-life. The Hexagon of Complexity (HexCom) is a complexity assessment model in the process of validation in health-care settings. Our objective is to use the instrument to describe differences in complexity across disease groups in specific home care for advanced disease and/or at the end-of-life patients, both in general and as relates to each domain and subdomain.

Methods: Cross-sectional study of home care was conducted in Catalonia. The instrument includes 6 domains of needs (clinical, psychological/emotional, social/family, spiritual, ethical, and death-related), 4 domains of resources (intrapersonal, interpersonal, transpersonal, and practical), and 3 levels of complexity (High $(\mathrm{H})$, Moderate $(\mathrm{M})$, and Low (L)). Interdisciplinary home care teams assessed and agreed on the level of complexity for each patient.

Results: Forty-three teams participated (74.1\% of those invited). A total of 832 patients were assessed, $61.4 \%$ of which were cancer patients. Moderate complexity was observed in $385(47.0 \%)$ cases and high complexity in 347 (42.4\%). The median complexity score was 51 for cancer patients and 23 for patients with dementia $(\mathrm{p}<0.001)$. We observed the highest level of complexity in the social/family domain. Patients/families most frequently used interpersonal resources $(80.5 \%)$.

Conclusions: This study sheds light on the high-intensity work of support teams, the importance of the social/family domain and planning the place of death, substantial differences in needs and resources across disease groups, and the importance of relationship wellbeing at the end-of-life.

Keywords: home care services, palliative care, terminally ill, terminal care, non-cancer patient, complexity, interdisciplinary research

\section{Background}

Complexity has become a core issue in caring for patients with advanced disease and/or at the end-of-life (AD/EOL patients). ${ }^{1-4}$ The very nature of end-of-life circumstances (which are ever-changing, unpredictable and full of contradictions, ambiguities, surprises, and insecurities) $)^{5}$ makes end-of-life care a paradigmatic situation of complexity. ${ }^{6,7}$ Applying traditional approaches (such as reductionism or compartmentalization) to complex situations may be counterproductive, which means it necessary to establish conceptual frameworks that accommodate the multiple dimensions of complexity through comprehensive and pragmatic approaches. ${ }^{8,9}$

Based on the definition of complexity levels and the inclusion and referral criteria of patients, ${ }^{10}$ a model for the care of people with advanced illness and/or 
at the end-of-life (the Hexagon of Complexity, HexCom) has been published ${ }^{11}$ and partially validated, ${ }^{12}$ with an inter-observer Kappa of 0.92

This model ${ }^{10,11}$ was created to address complexity in Catalonia (Spain). It is based on the conceptual framework of the Multiple Chronic Conditions Research Network of the University of Washington, which defines complexity as the "gap between patient needs and healthcare services," 13 or rather, a mismatch between patient needs and services. ${ }^{4}$ The instrument defines situations that are refractory to treatment options as "high complexity," and situations that are difficult to resolve as "moderate complexity." In this sense, classifying patients according to the level of complexity they present helps distinguish between those who need specialized palliative care and those who do not. ${ }^{14}$

Based on the work of Ferris, the model (Figures 1 and 2) offers six domains of need (clinical, psychological/emotional, social/family, spiritual, ethical, and death-related), which are broken down into 18 subdomains. ${ }^{2,15}$ The level of complexity for each domain or subdomain can be low, moderate, or high. The model also includes four domains of resources or strengths (intrapersonal, interpersonal, transpersonal, and practical) based on a consensual model of spirituality by Puchalski and which is applied in our clinical practice. $^{16,17}$

The literature provides information on the relevance of the family in home care, as both the caregiver and recipient of care, which clearly distinguishes home care from institutional care. ${ }^{18}$ It also describes varying needs according to the different pathologies that result in death. ${ }^{19}$ These most prevalent of these diseases can be grouped into five categories: cancer, organ failure, neurological disorders, dementia, and frailty/multimorbidity. ${ }^{3,20,21}$

Our objective is to use the instrument to describe differences in complexity across disease groups in specific home care for $\mathrm{AD} / \mathrm{EOL}$ patients, both in general and as relates to each domain and subdomain.

\section{Complexity Hexagon (HexCom-Clin ${ }^{2018}$ )}

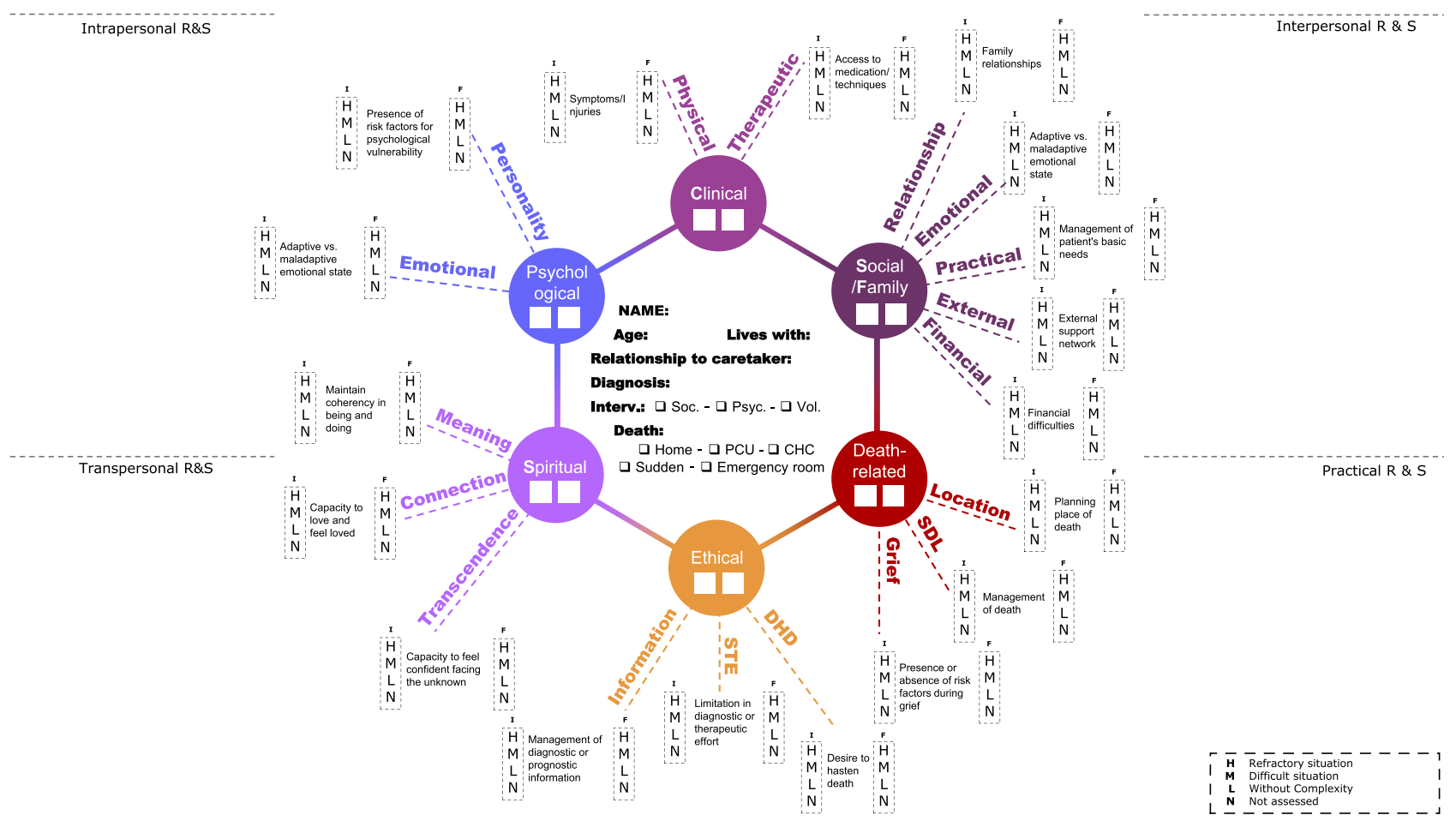

Figure I HexCom form (previous page): analysis of needs.

Notes: Collects information about the Complexity observed in each domain and subdomain of Necessity, at the beginning (I) and at the end (F) of the Follow-up, with 3 complexity levels: High (H) (Refractory situation), Medium (M) (Difficult situation), Low (L) (Without Complexity), or $\mathrm{N}$ if it cannot be assessed. R\&S: Resources \& Strengths; STE: Suitability of treatment efforts; DHD: Desire to hasten death; SLD: Situation during last days of life. Interv: interveners. Soc: Social worker; Psyc: Psychologist; Vol: Volunteer; PCU: Palliative care unit; CHC: Hospital. 


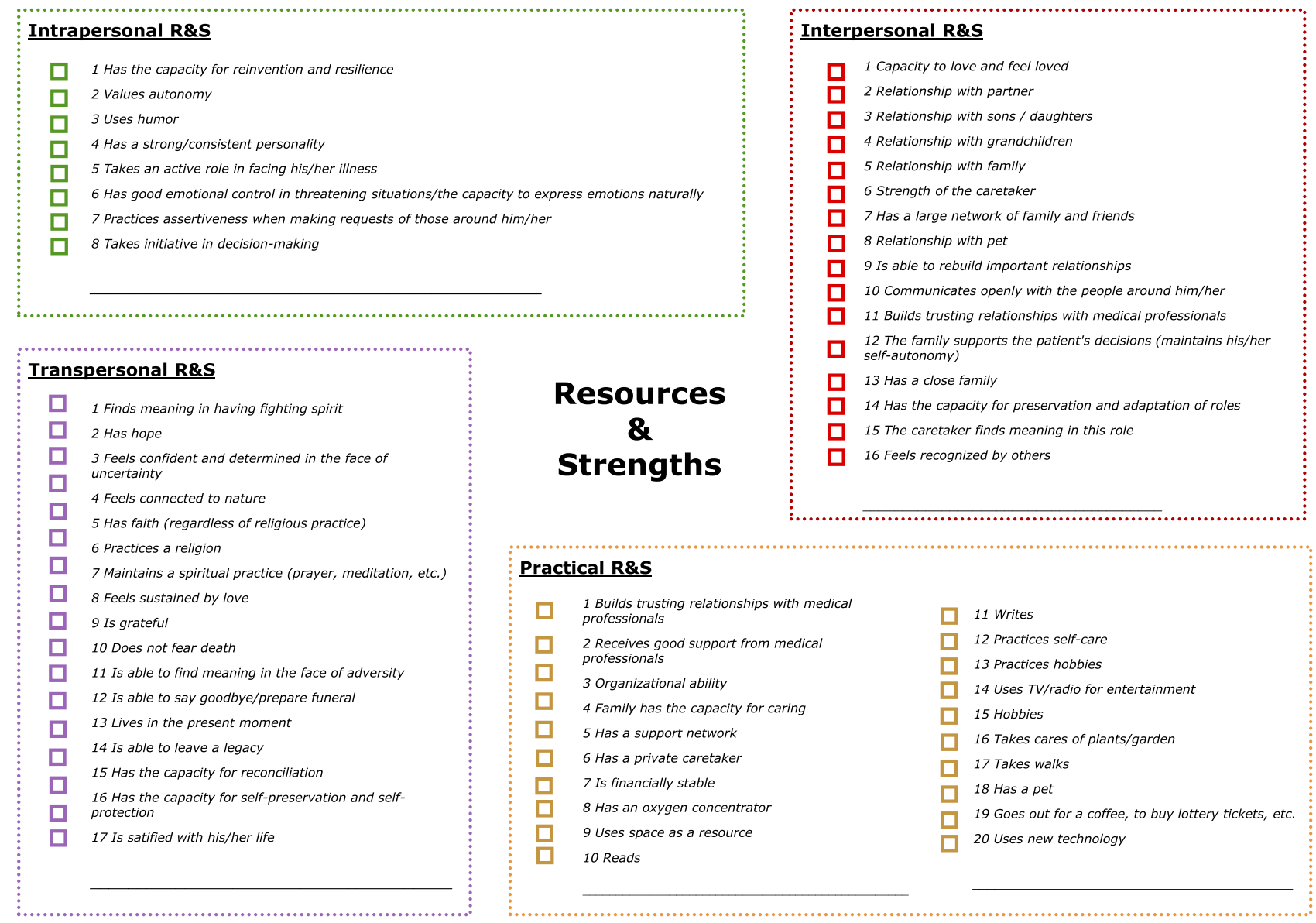

Figure 2 HexCom form (later page): analysis of resources and strengths.

Notes: Collects information about Resources and Strengths observed in the home and that help sustain the actual situation. It is indicated if resource determination is detected. Abbreviation: R\&S, resources and strengths.

\section{Methods}

\section{Design: Cross-Sectional Study} Study Population: AD/EOL Patients Treated by PADES Teams at Catalonia (Spain)

In Catalonia, home care is shared between primary care services and home care support teams (PADES teams). PADES teams support primary and community care by visiting the homes of patients with complex cases who may benefit from interdisciplinary and specialized intervention. Generally, they are made up of medical, nursing, and social-work staff, although some teams also include physiotherapists, occupational therapists and/or psychologists. In 2015, PADES teams treated 15,337 patients, thus providing coverage for $34.8 \%$ of patients at the end-of-life. ${ }^{22}$ PADES teams have demonstrated effectiveness, efficiency, and user satisfaction. ${ }^{23,24}$ There are 1.15 PADES teams per 100,000 inhabitants. However, it is worth pointing out the significant differences in structure, dedication, and training across these teams ${ }^{25}$ as well as the impact of budget cuts to health care. ${ }^{26}$
Inclusion/exclusion criteria: Patients with advanced disease and/or at the end-of-life attended by PADES teams at their home. Patients who received care in a residential institution are excluded. We used consecutive sampling during the recruitment period $(15 / 02 / 6$ to $15 / 12 / 16)$ to assign patients that met inclusion requirements to one of the PADES teams that agreed to participate in the study.

\section{Variables Level of Complexity (Outcome)}

The instrument includes six domains of needs (clinical, psychological, spiritual, social/family, ethical, and deathrelated) and 18 subdomains (Figures 1 and 2).

Each domain and subdomain may be classified according to three qualitative levels of complexity:

- High $(\mathrm{H})$ : Refractory situation, in which suffering occurs

- Moderate (M): Difficult situation that requires shared care 
- Low (L): Low-level complexity

- Not Assessed (NA): Domain cannot be assessed.

The PADES team of each patient came to a consensus on the level of complexity she/he presented for each subdomain. Then, each domain takes its score from the highest degree of complexity observed in any of its subdomains. The overall level of complexity is, in turn, based on the highest level of complexity observed in any of the six domains.

Both high and moderate complexity require intervention from a PADES team. This is why we established the dichotomous variable "high/moderate complexity" vs "low complexity."

\section{Complexity Score}

We calculated complexity scores by first determining the total number of domains classified as $\mathrm{H}, \mathrm{M}$, and $\mathrm{L}$. These totals were then multiplied as follows: Hx100, Mx10, and Lx1 (the NA category was excluded). The result is an ordinal variable that constitutes a complexity score for each patient in which the hundredth place represents the total number of $\mathrm{Hs}$, the decimal place represents the total number of Ms and the ones place represents the total number of Ls. Therefore, a patient with a score of 231 has $2 \mathrm{Hs}$, three Ms, and one L (and no NAs). In this way, we were able to obtain a complexity score for each patient.

\section{Resource and Strength Domains}

These domains address the values, attitudes, and beliefs that promote adaptation and/or the potential for transformation (change) as demonstrated by the patient/family in facing the end-of-life situation. They are divided into four domains (intrapersonal, interpersonal, transpersonal, and practical).

Disease groups: Medical diagnosis (ICD-10) and advanced disease groups: cancer, advanced chronic organ failure, neurological disorders, dementia, or geriatric frailty. Concomitant diagnosis of dementia (Yes/No). The PADES team came to a consensus about which diagnosis most greatly contributed to the process of death for each patient and classified him or her accordingly.

\section{Another Information}

- Socio-demographic data (age, gender, relationship to caretaker, family support worker).

- Patient's status: functional status (Barthel Index) and mental status (SPMSQ).
- Health-care data: duration (total days) of home care; total number of visits during home care, psychologist, social worker, and volunteer visits.

- Location of death and cause of PADES team discharge.

- PADES team characteristics.

Training and data collection process: The Department of Health of the Government of Catalonia invited all 58 Catalan PADES teams to participate in this study. In total, 52 of these teams $(89.6 \%)$ participated in one or two inperson training sessions at the Department of Health headquarters. The sessions lasted $5 \mathrm{hrs}$ each and participants watched four videos of clinical cases to learn how to use the instrument and standardize data collection and compilation. Participants received a user's guide and were offered a phone number to call should they have doubts during fieldwork. PADES teams assessed complexity using the instrument during interdisciplinary meetings after at least one home visit. They used an online formula to enter information into a centralized database, which contained no personal data that could reveal patient identity.

\section{Statistical Analysis}

Categorical variables are expressed as the absolute frequency and percentage. The Kolmogorov-Smirnov test was used to determine the normality of the quantitative variables and their frequency histogram, skewness, and kurtosis were inspected. Quantitative variables are described as the mean and standard deviation or the median and first and third quartiles (Q1-Q3) for those with a non-normal distribution. We used Pearson's Chi-square test to compare proportions, the Student's $t$-test for continuous variables, and the Kruskal-Wallis test for ordinal variables or non-normal variables.

Complexity was evaluated by combining "moderate" and "high" into one category, thus establishing a dichotomous variable ("high/moderate complexity" vs "low complexity").

We used the Chi-square test to compare the prevalence of "moderate/high complexity" across disease groups and analyzed the standardized residual as a measure of the strength of the difference between observed and expected values: if the residual was less than -1.96 , the observed frequency of the cell was less than the expected frequency; if it was greater than 1.96 , the observed frequency was greater than the expected frequency.

Statistical significance for comparisons was $\mathrm{p} \leq 0.05$. All analyses were performed with SPSS for Windows, version 23.0. 


\section{Ethics Committee Approval}

The study was approved by the Clinical Research Ethics Committee of the University Insitute of Research in Primary Care (IDIAP) Jordi Gol (registration number P15/171) and by the clinical research ethics committees of all participating centers. All participants read and signed an informed consent form.

\section{Results}

A total of 43 PADES teams ( $74.1 \%$ of those invited) participated in the study. We recruited $832 \mathrm{AD} / \mathrm{EOL}$ patients for the study: 511 (61.4\%) had cancer and 321 had non-cancer diseases (38.6\%) (Table 1). The mean age was 78.73 $(\mathrm{SD}=13.0)$ and 394 (47.6\%) participants were female. Patients' partners took on the role of caretaker in $40.4 \%$ of cases and their sons/daughters did so in $41.9 \%$. In 554 (66.9\%) cases there was no involvement of a family support worker. Patients presented moderate functional dependency (Barthel Index mean: 49.83), and a total of $566(68.3 \%)$ participants presented no cognitive impairment.

We observed differences in socio-demographic data as well as status between groups as regards age, gender,

Table I Main Variables: Total and per Disease Group

\begin{tabular}{|c|c|c|c|c|c|c|c|}
\hline & Cancer & Organ Failure & $\begin{array}{l}\text { Neurological } \\
\text { Disorders }\end{array}$ & Dementia & $\begin{array}{l}\text { Frailty/ } \\
\text { Multimorbidity }\end{array}$ & Total & \\
\hline $\mathrm{N}(\%)$ & $511(61.4 \%)$ & $168(20.1 \%)$ & $47(5.6 \%)$ & $78(9.3 \%)$ & $26(3.1 \%)$ & $832(100 \%)$ & $P$ \\
\hline Average age $^{\mathrm{a}}$ & $74.5(12.3)$ & $85 . I(8.8)$ & $77.7(17.9)$ & $89.5(7.8)$ & $90.12(8.6)$ & $78.7(13.0)$ & $<0.001^{\mathrm{e}}$ \\
\hline Range & $22-100$ & $53-105$ & $24-101$ & $66-107$ & $70-101$ & $22-107$ & \\
\hline Female & $213(41.8 \%)$ & $80(47.6 \%)$ & $30(63.8 \%)$ & $56(71.8 \%)$ & $15(57.7 \%)$ & 394 (47.6\%) & $<0.001^{f}$ \\
\hline Caretaker: & & & & & & & $<0.001^{f}$ \\
\hline Partner & $253(49.9 \%)$ & $49(29.3 \%)$ & II (23.4\%) & $17(2 \mid .8 \%)$ & $3(11.5 \%)$ & $333(40.4 \%)$ & \\
\hline Children & $18 \mid(35.7 \%)$ & $77(46.1 \%)$ & $23(48.9 \%)$ & $46(59.0 \%)$ & $19(73.1 \%)$ & $346(41.9 \%)$ & \\
\hline Other Fam & $35(6.9 \%)$ & $17(10.2 \%)$ & $7(14.9 \%)$ & $7(9.0 \%)$ & $\mathrm{I}(3.8 \%)$ & $67(8.1 \%)$ & \\
\hline Other & $38(7.5 \%)$ & $24(14.4 \%)$ & $6(12.8 \%)$ & $8(10.3 \%)$ & $3(11.5 \%)$ & $79(9.6 \%)$ & \\
\hline External caretaker & & & & & & & $<0.001^{f}$ \\
\hline No & $385(75.6 \%)$ & $94(56.0 \%)$ & $21(44.7 \%)$ & $40(51.3 \%)$ & $14(53.8 \%)$ & $554(66.9 \%)$ & \\
\hline Part time & $82(16.1 \%)$ & $42(25.0 \%)$ & $18(38.3 \%)$ & $20(25.6 \%)$ & $9(34.6 \%)$ & $|7|(20.7 \%)$ & \\
\hline $24 \mathrm{hrs}$ & $42(8.3 \%)$ & $32(19.0 \%)$ & $8(17.0 \%)$ & $18(23.1 \%)$ & $3(11.5 \%)$ & $103(12.4 \%)$ & \\
\hline $\begin{array}{l}\text { Functional status } \\
(\text { Barthel Index })^{\mathrm{a}}\end{array}$ & $61.9(27.3)$ & $48.3(28.9)$ & $13.1(15.5)$ & $6.2(12.8)$ & 19.8(27.7) & $49.8(32.4)$ & $<0.001^{\mathrm{e}}$ \\
\hline Cognitive impairment & & & & & & & $<0.001^{f}$ \\
\hline No & $419(82.2 \%)$ & $113(67.3 \%)$ & $18(38.3 \%)$ & $0(0.0 \%)$ & | 4(53.8\%) & $566(68.3 \%)$ & \\
\hline Mild & $46(9.0 \%)$ & $21(12.5 \%)$ & $9(19.1 \%)$ & $\mathrm{I}(\mathrm{I} .3 \%)$ & $6(23.1 \%)$ & $83(10.0 \%)$ & \\
\hline Moderate & $26(5.1 \%)$ & $18(10.7 \%)$ & $2(4.3 \%)$ & $7(9.2 \%)$ & $3(11.5 \%)$ & $56(6.8 \%)$ & \\
\hline Severe & $19(3.7 \%)$ & $16(9.5 \%)$ & $18(38.3 \%)$ & $68(89.5 \%)$ & $3(11.5 \%)$ & $124(15.0 \%)$ & \\
\hline \multirow[t]{3}{*}{ Medical diagnosis ${ }^{\mathrm{b}}$} & C34: 123 & I50: $58(34.5 \%)$ & G3I: 26(55.3\%) & G30: 46 & R54: I2(46.2\%) & & \\
\hline & $(24.1 \%)$ & J44: $51(30.4 \%)$ & GI2: 8(I7.0\%) & (59.0\%) & I70: $4(15.4 \%)$ & & \\
\hline & $\begin{array}{l}\text { C18: } 68 \\
(13.3 \%)\end{array}$ & & & $\begin{array}{l}\text { G3I: } 25 \\
(32.1 \%)\end{array}$ & & & \\
\hline Dementia $^{c}$ & $33(6.5 \%)$ & $25(14.9 \%)$ & $20(42.6 \%)$ & $75(100 \%)$ & $5(19.2 \%)$ & $158(19.1 \%)$ & $<0.001^{f}$ \\
\hline Total days $^{\mathrm{d}}$ & $3 I(14-65)$ & $37.5(16.25-104.00)$ & $35(|3-| 16.25)$ & $37.5(9-68.5)$ & $13.5(4.75-60.75)$ & $33(14-74)$ & $0.064^{g}$ \\
\hline PADES visits ${ }^{d}$ & $5(3-9)$ & $5(3-10)$ & $5(2-9.25)$ & $4(2-7)$ & $3(2-7.25)$ & $5(2-9)$ & $0.240^{g}$ \\
\hline Social worker visit & $337(66.7 \%)$ & $120(71.9 \%)$ & $37(80.4 \%)$ & $49(63.6 \%)$ & $13(50.0 \%)$ & $556(67.7 \%)$ & $0.055^{f}$ \\
\hline Psychologist visit & $135(26.7 \%)$ & $17(10.3 \%)$ & II (23.9\%) & $8(10.7 \%)$ & $2(7.7 \%)$ & $173(21.2 \%)$ & $<0.001^{\mathrm{f}}$ \\
\hline Complexity Score $^{\mathrm{d}}$ & $5 I(24-20 I)$ & $33(23-132)$ & $32(22-213)$ & $23(11.5-111)$ & $32.5(2 I-122)$ & $42(23-14 \mid)$ & $<0.001^{g}$ \\
\hline
\end{tabular}

Notes: $\mathrm{N}(\%)$ : number of patients in each disease group and their percentage with respect to the total. PADES: Home care support team program. ${ }^{a}$ Mean and Standard Deviation; 'ICD-10 Code: C34: Neoplasm of lungs; C18: Neoplasm of colon; 150: Heart failure; J44: Chronic obstructive pulmonary disease; G3I: Degenerative diseases of the nervous system; GI2: Motor neuron disease; G30: Alzheimer's disease; R54: Senility; 170: Atherosclerosis. ${ }^{\circ}$ Concomitant dementia. ${ }^{d}$ Median. 25 th and 75 th percentiles; ${ }^{e}$ t Student test; ${ }^{\mathrm{f}}$ Chi-square test; ${ }^{\mathrm{g}} \mathrm{Kruskal}-\mathrm{W}$ allis test. 
relationship to caretaker, family support worker, and cognitive and functional status $(\mathrm{p}<0.001)$ (Table 1). The cancer group had the youngest mean age and the greatest number of participants. Cancer patients' partners usually took on the role of caretaker and patients presented the best mental and functional status. Other groups consisted predominantly of older (except for the neurological disorders group, which was younger) females (except for the organ failure group, in which gender was equally distributed). Patients in these groups were mostly cared for by their sons/daughters with the aid of a family support worker and presented worse functional and mental status. Neoplasm of the lungs, advanced heart failure, degenerative disorders of the central nervous system, Alzheimer's disease, and senility were the most common diagnoses for each group. We observed a high prevalence of concomitant dementia $(42.6 \%)$ in the neurological disorders group.

Patients received home care for a total of 33 days on average, during which they received an average of 5 visits, without much variance across groups. The majority of patients received visits from social workers (67.7\%), especially those in the neurological disorders and organ failure groups $(80.4 \%$ and $71.9 \% ; \mathrm{p}=0.05)$. Psychologists treated $173(21.2 \%)$ patients, above all those in the cancer and neurological disorders groups (26.7\% and 23.9\%; $\mathrm{p}<0.001)$. Volunteer support was less than $1.5 \%$.

Most patients presented either moderate 385 (47.0\%) or high 347 (42.4\%) complexity. We observed the highest level of complexity (Score 51) in the cancer group and the lowest level (Score 23) in the dementia group $(\mathrm{p}<0.001)$ (Table 1, Figure 3).

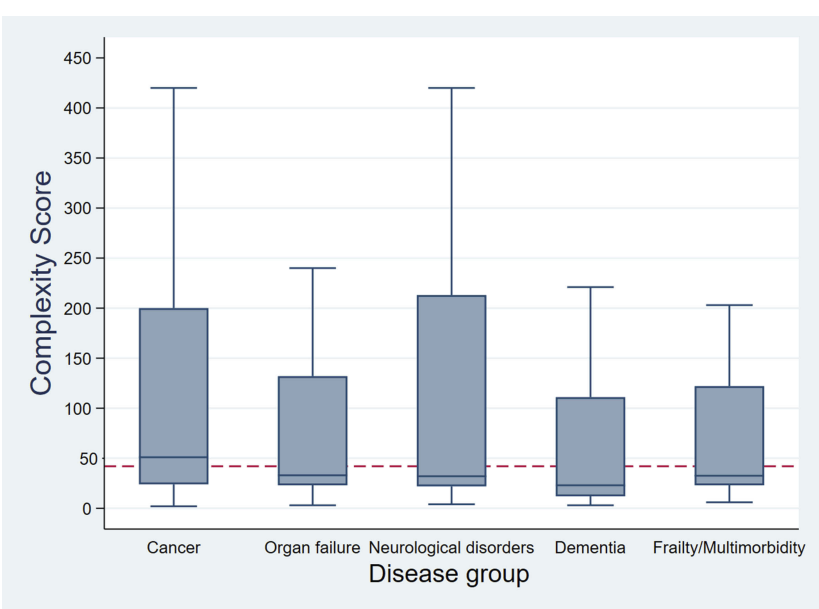

Figure 3 Comparison of complexity scores of each disease group. Note: The dashed line represents the median Complexity Score of all participants.
Table 2 Level of Complexity per Domain, Subdomain, and Global

\begin{tabular}{|c|l|l|l|}
\hline \multirow{2}{*}{ Domain/Subdomain } & \multicolumn{2}{l}{ Complexity } \\
\cline { 2 - 4 } & Low & Moderate & High \\
\hline Clinical & $297(36.3 \%)$ & $387(47.3 \%)$ & $135(16.5 \%)$ \\
Physical & $336(41.1 \%)$ & $365(44.6 \%)$ & $127(14.3 \%)$ \\
Therapeutic & $502(61.5 \%)$ & $243(29.8 \%)$ & $71(8.7 \%)$ \\
\hline Psychological & $415(52.3 \%)$ & $279(35.2 \%)$ & $99(12.5 \%)$ \\
Personality & $594(76.4 \%)$ & $130(16.7 \%)$ & $53(6.8 \%)$ \\
Emotional & $419(55.7 \%)$ & $251(33.4 \%)$ & $82(10.9 \%)$ \\
\hline Spiritual & $441(68.7 \%)$ & $150(23.4 \%)$ & $51(7.9 \%)$ \\
Meaning & $420(74.5 \%)$ & $105(18.6 \%)$ & $39(6.9 \%)$ \\
Connection & $530(84.1 \%)$ & $73(11.6 \%)$ & $27(4.3 \%)$ \\
Transcendence & $384(73.1 \%)$ & $110(21.0 \%)$ & $31(5.9 \%)$ \\
\hline Social/Family & $257(31.4 \%)$ & $364(44.4 \%)$ & $198(24.2 \%)$ \\
Relationships & $534(65.5 \%)$ & $210(25.8 \%)$ & $71(8.7 \%)$ \\
Emotional & $425(52.5 \%)$ & $289(35.7 \%)$ & $96(11.9 \%)$ \\
Practical & $454(55.7 \%)$ & $267(32.8 \%)$ & $94(11.5 \%)$ \\
External & $420(54.6 \%)$ & $254(33.0 \%)$ & $95(12.4 \%)$ \\
Financial & $668(85.3 \%)$ & $82(10.5 \%)$ & $33(4.2 \%)$ \\
\hline Ethical & $554(70.4 \%)$ & $169(21.5 \%)$ & $64(8.1 \%)$ \\
Information & $601(81.5 \%)$ & $91(12.3 \%)$ & $45(6.1 \%)$ \\
STE & $556(80.3 \%)$ & $112(16.2 \%)$ & $24(3.5 \%)$ \\
DHD & $540(87.7 \%)$ & $59(9.6 \%)$ & $17(2.8 \%)$ \\
\hline Death-related & $313(42.2 \%)$ & $272(36.7 \%)$ & $156(21.1 \%)$ \\
Place & $290(48.5 \%)$ & $175(29.3 \%)$ & $133(22.2 \%)$ \\
SLD & $171(62.6 \%)$ & $61(22.3 \%)$ & $41(15.0 \%)$ \\
Grief & $459(62.8 \%)$ & $201(28.6 \%)$ & $44(6.3 \%)$ \\
\hline Global complexity & $87(10.6 \%)$ & $385(47.0 \%)$ & $347(42.4 \%)$ \\
\hline
\end{tabular}

Abbreviations: STE, suitability of treatment efforts; DHD, desire to hasten death; SLD, situation during last days of life.

Table 2 presents a summary of complexity observed in all patients. High complexity was most frequent in the social/family domain $(24.2 \%)$ and in the place-of-death subdomain $(22.2 \%)$, while it was least frequent in the ethical (8.1\%) and spiritual (7.9\%) domains.

Table 3 compares "Moderate or high complexity" across disease groups: clinical and physical complexity were highest in the organ failure group and lowest in the dementia group.

\section{Psychological Complexity Was Lowest in the Dementia Group}

Spiritual complexity was lowest in the dementia group and the subdomain of transcendence was lowest in the organ failure group. Social/family complexity was lowest in the frailty/multimorbidity groups. Ethical complexity was lowest in the organ failure group. Death-related complexity and its 
Table 3 Differences in Complexity Across Disease Groups: Patients with Moderate or High Complexity (N\%)

\begin{tabular}{|c|c|c|c|c|c|c|c|}
\hline Domain/Subdomain & Cancer & $\begin{array}{l}\text { Organ } \\
\text { Failure }\end{array}$ & $\begin{array}{l}\text { Neurological } \\
\text { Disorder }\end{array}$ & Dementia & $\begin{array}{l}\text { Frailtyl } \\
\text { Multimorbidity }\end{array}$ & Total & $\mathbf{P}$ \\
\hline Clinical & $318(63.0 \%)$ & $|2|(73.3 \%)^{a}$ & $30(63.8 \%)$ & $36(47.4 \%)^{b}$ & 17 (65.4\%) & $522(63.7 \%)$ & 0.004 \\
\hline Physical & 292 (57.9\%) & $1 / 4(69.1 \%)^{a}$ & $28(59.6 \%)$ & $31(40.8 \%)^{b}$ & 17 (65.4\%) & 482 (58.9\%) & 0.001 \\
\hline Therapeutic & 192 (38.2\%) & 73 (44.2\%) & $17(37.0 \%)$ & $22(28.9 \%)$ & $10(38.5 \%)$ & $314(38.5 \%)$ & 0.258 \\
\hline Psychological & 252 (50.5\%) & 71 (44.9\%) & $24(54.5 \%)$ & $22(32.8 \%)^{b}$ & $9(36.0 \%)$ & $378(47.7 \%)$ & 0.037 \\
\hline Personality & 119 (24.3\%) & 38 (24.5\%) & $8(18.6 \%)$ & 14 (21.9\%) & $4(16.0 \%)$ & $183(23.6 \%)$ & 0.790 \\
\hline Emotional & 224 (46.0\%) & $64(43.0 \%)$ & 21 (55.3\%) & 15 (27.3\%) & 9 (39.1\%) & $333(44.3 \%)$ & 0.055 \\
\hline Spiritual & 149 (33.6\%) & 38 (29.7\%) & $9(33.3 \%)$ & I $(3.7 \%)^{b}$ & $4(23.5 \%)$ & 201 (31.3\%) & 0.023 \\
\hline Meaning & $103(26.4 \%)$ & $29(24.2 \%)$ & $8(38.1 \%)$ & I (6.3\%) & $3(17.6 \%)$ & I 44 (25.5\%) & 0.222 \\
\hline Connection & 71 (16.2\%) & 24 (19.0\%) & $3(11.5 \%)$ & $0(0.0 \%)$ & 2 (II.8\%) & 100 (15.9\%) & 0.191 \\
\hline Transcendence & $110(30.5 \%)$ & $20(17.2 \%)^{b}$ & $7(36.8 \%)$ & $0(0.0 \%)^{b}$ & $4(23.5 \%)$ & $|4|(26.9 \%)$ & 0.010 \\
\hline Social/Family & $348(68.9 \%)$ & 121 (73.3\%) & $34(72.3 \%)$ & 47 (61.8\%) & $12(46.2 \%)^{b}$ & $562(68.6 \%)$ & 0.045 \\
\hline Relationships & $172(34.1 \%)$ & 64 (39.3\%) & $18(38.3 \%)$ & $20(26.7 \%)$ & 7 (26.9\%) & $28 I(34.5 \%)$ & 0.323 \\
\hline Emotional & $236(47.0 \%)$ & 80 (49.4\%) & 27 (58.7\%) & 32 (43.2\%) & $10(38.5 \%)$ & 385 (47.5\%) & 0.409 \\
\hline Practical & $222(44.0 \%)$ & $80(48.8 \%)$ & $23(48.9 \%)$ & 28 (37.3\%) & $8(32.0 \%)$ & 361 (44.3\%) & 0.312 \\
\hline External & $210(44.0 \%)$ & 83 (52.9\%) & 19 (47.5\%) & 28 (39.4\%) & 9 (37.5\%) & 349 (45.4\%) & 0.232 \\
\hline Financial & 74 (I5.2\%) & $25(16.0 \%)$ & $3(7.5 \%)$ & 8 (10.7\%) & $5(20.0 \%)$ & 115 (14.7\%) & 0.477 \\
\hline Ethical & $156(31.6 \%)$ & $42(26.3 \%)$ & $14(31.8 \%)$ & $13(20.0 \%)$ & 8 (33.3\%) & $233(29.6 \%)$ & 0.295 \\
\hline Information & $109(23.0 \%)$ & $16(10.5 \%)^{b}$ & $4(10.5 \%)$ & $4(7.7 \%)^{b}$ & $3(13.6 \%)$ & $136(18.5 \%)$ & 0.001 \\
\hline $\begin{array}{l}\text { Suitability of treatment } \\
\text { efforts }\end{array}$ & 78 (I8.7\%) & 27 (I8.6\%) & $12(29.3 \%)$ & $12(18.5 \%)$ & 7 (29.2\%) & $136(19.7 \%)$ & 0.384 \\
\hline Desire to hasten death & 50 (12.9\%) & $16(12.2 \%)$ & $3(9.1 \%)$ & $3(7.0 \%)$ & $4(20.0 \%)$ & $76(12.3 \%)$ & 0.618 \\
\hline Death & $283(61.9 \%)$ & $82(58.2 \%)$ & $21(46.7 \%)$ & $28(38.9 \%)^{b}$ & $14(53.8 \%)$ & $428(57.8 \%)$ & 0.003 \\
\hline Location & $215(58.9 \%)^{a}$ & $59(54.1 \%)$ & $10(30.3 \%)^{b}$ & $15(22.7 \%)^{b}$ & $9(36.0 \%)$ & $308(51.5 \%)$ & 0.000 \\
\hline Situation of last days & 67 (42.7\%) & $18(36.0 \%)$ & 5 (29.4\%) & $6(18.8 \%)$ & $6(35.3 \%)$ & $102(37.4 \%)$ & 0.128 \\
\hline Grief & 169 (38.9\%) & 39 (29.5\%) & $17(38.6 \%)$ & $14(20.6 \%)^{b}$ & $6(24.0 \%)$ & 245 (34.8\%) & 0.015 \\
\hline
\end{tabular}

Notes: $\mathrm{N}(\%)$ : number of patients in each disease group and their percentage with respect to the total. The significant differences according to the standardized residuals for Pearson's Chi-square test are marked in bold: ${ }^{a}$ Greater than 1.96 (observed frequency is greater than expected); ${ }^{b}$ Less than -1.96 (observed frequency is less than expected).

subdomains of location, situation of last days and grief were lowest in the dementia group, while the location subdomain was highest in the cancer group.

Regarding resources used to face the situation, cancer patients most frequently used all three types of resources, whereas dementia patients used them least frequently (Table 4). Patients with organ failure most frequently used practical resources and those with neurological disorders used transpersonal resources least frequently.

\section{Discussion}

There are significant differences in needs and resources across disease groups: cancer patients presented the greatest complexity, while dementia patients made the least use of resources. ${ }^{27}$

Complexity was greatest in the social/family domains and place of death. Interpersonal resources (positive relationships) were the type most frequently employed to cope with the end-of-life situation. ${ }^{28}$

In specialized home care, the situations professionals attend to are highly complex and transitory.

Our results corroborate those found in the bibliography. In one study, a home hospitalization team found that $79 \%$ of patients presented highly complex situations. ${ }^{29} \mathrm{We}$ also know that the needs of cancer patients are radically different from those of terminal patients with organ failure. . $^{19,20,30,31}$ Waller observed physical complexity in $51 \%$ of participants, practical social/family complexity in $33 \%$, and high spiritual complexity in $8.8 \% .{ }^{32}$ Waller also observed high psychological/emotional complexity in $38.8 \%$ of patients. Both Waller's figures and ours are greater than those found by Potash, who noted that between $20 \%$ and $35 \%$ of patients required specific psychological care. ${ }^{33}$ Regarding the ethical domain, Chochinov found that $8.5 \%$ of patients persistently 
Table 4 Resources and Strengths Used to Face the End-of-Life Across Disease Groups

\begin{tabular}{|c|c|c|c|c|c|c|c|}
\hline Domain/Subdomain & Cancer & $\begin{array}{l}\text { Organ } \\
\text { Failure }\end{array}$ & $\begin{array}{l}\text { Neurological } \\
\text { Disorders }\end{array}$ & Dementia & $\begin{array}{l}\text { Frailty } \\
\text { Multimorbidity }\end{array}$ & Total & $\mathbf{P}$ \\
\hline Intrapersonal & $410(80.1 \%)^{a}$ & $\mid 20(7 \mid .4 \%)$ & $27(57.4 \%)^{b}$ & $32(41.0 \%)^{b}$ & $17(63.0 \%)$ & $606(72.8 \%)$ & $<0.001$ \\
\hline $\begin{array}{l}\text { Strong and resilient } \\
\text { personality }\end{array}$ & $221(43.2 \%)^{a}$ & $61(36.3 \%)$ & $13(27.7 \%)$ & $15(19.2 \%)^{b}$ & II (40.7\%) & $321(38.6 \%)$ & 0.001 \\
\hline Self-decision making & $327(63.9 \%)^{a}$ & $94(56.0 \%)$ & $20(42.6 \%)$ & $7(9.0 \%)^{b}$ & $10(37 \%)^{b}$ & $458(55.0 \%)$ & $<0.001$ \\
\hline Self-emotional control & $311(60.7 \%)^{a}$ & $81(48.2 \%)$ & $19(40.4 \%)$ & $20(25.6 \%)^{b}$ & $10(37 \%)$ & $44 \mid(53.0 \%)$ & $<0.001$ \\
\hline Interpersonal & $439(85.7 \%)^{a}$ & $126(75.0 \%)^{b}$ & $35(74.5 \%)$ & $53(67.9 \%)^{b}$ & $17(63.0 \%)^{b}$ & $670(80.5 \%)$ & $<0.001$ \\
\hline Capacity to feel loved & $305(59.6 \%)$ & $98(58.3 \%)$ & $27(57.4 \%)$ & $39(50 \%)$ & $15(55.6 \%)$ & $484(58.2 \%)$ & 0.620 \\
\hline Positive relationships & $387(75.6 \%)^{a}$ & $107(63.7 \%)$ & $26(55.3 \%)^{b}$ & $37(47.4 \%)^{b}$ & $16(59.3 \%)$ & $573(68.9 \%)$ & $<0.001$ \\
\hline $\begin{array}{l}\text { Family \& Roles: caring family } \\
\text { environment }\end{array}$ & $258(50.4 \%)^{a}$ & $69(41.1 \%)$ & $20(42.6 \%)$ & $26(33.3 \%)^{b}$ & $13(48.1 \%)$ & $386(46.4 \%)$ & 0.028 \\
\hline Transpersonal & $359(70.1 \%)^{a}$ & $111(66.1 \%)$ & $21(44.7 \%)^{b}$ & $\mid 7(2 \mid .8 \%)^{b}$ & $16(59.2 \%)$ & $524(63.0 \%)$ & $<0.001$ \\
\hline $\begin{array}{l}\text { Future-focused: confident } \\
\text { about the future }\end{array}$ & $273(53.3 \%)^{a}$ & $85(50.6 \%)$ & $14(29.8 \%)^{b}$ & $3(3.8 \%)^{b}$ & $12(44.4 \%)$ & $387(46.5 \%)$ & $<0.001$ \\
\hline $\begin{array}{l}\text { Present-focused: living the } \\
\text { here \& now }\end{array}$ & $263(51.4 \%)^{a}$ & $77(45.8 \%)$ & $13(27.7 \%)^{b}$ & $14(17.9 \%)^{b}$ & $9(33.3 \%)$ & $376(45.2 \%)$ & $<0.001$ \\
\hline Religiosity and rituals & $86(16.8 \%)$ & $34(20.2 \%)$ & $6(12.8 \%)$ & $6(7.7 \%)$ & $7(25.9 \%)$ & $139(16.7 \%)$ & 0.083 \\
\hline Practical & $364(71.1 \%)$ & $|3|(78 \%)^{a}$ & $32(68.1 \%)$ & $33(42.3 \%)^{b}$ & $19(70.4 \%)$ & $579(69.6 \%)$ & $<0.001$ \\
\hline $\begin{array}{l}\text { Organization: organizational } \\
\text { capacity }\end{array}$ & $289(56.4 \%)$ & $105(62.5 \%)$ & $29(61.7 \%)$ & $33(42.3 \%)$ & $15(55.6 \%)$ & $47 \mid(56.6 \%)$ & 0.052 \\
\hline Capacity to entertain oneself & $2 \mid 4(41.8 \%)^{a}$ & $79(47.0 \%)^{a}$ & $12(25.5 \%)$ & $3(3.8 \%)^{b}$ & $9(33.3 \%)$ & $317(38.1 \%)$ & $<0.001$ \\
\hline
\end{tabular}

Notes: The significant differences according to the standardized residuals for Pearson's Chi-square test are marked in bold: ${ }^{a} \mathrm{Greater}$ than I.96 (observed frequency is greater than expected); 'Less than -1.96 (observed frequency is less than expected).

desired to hasten death. ${ }^{34}$ A recent systematic review yielded great variability in results for this subdomain, ranging from $3.3 \%$ to $28 \%{ }^{35}$ Lastly, prevalence of moderate to high complexity indicators of grief was $32 \%^{36}$ and prevalence of pathological grief was $28 \%{ }^{37}$

The fact that the highest level of clinical (physical) complexity was observed in the organ failure group is likely related to a less predictable trajectory and development of crises in these diseases. ${ }^{38}$ The higher level of psychological (emotional) complexity observed in the neurological disorders group is perhaps related to the expectation of loss over a longer period of time..$^{39,40}$

The low level of complexity in the dementia group may be related to cognitive impairment presented by patients. ${ }^{41-43}$ The lower level of ethical and spiritual complexity observed may be related to the difficulty that health-care professionals had in detecting these needs. ${ }^{44}$ Based on the open comments collected in the survey, it is clear that teams had a heavy workload and some difficulty in clearly defining some of the contents of the assessment tool, especially those related to spiritual needs. While clinical complexity is described as undeterminable in $0.2 \%$ of cases, this percentage reaches $22.6 \%$ in the subdomain of connection, $29.7 \%$ in meaning, and $35.5 \%$ in transcendence.

We know that unmet needs in end-of-life care are mostly related to communication issues. ${ }^{45}$ Thus, by promoting team consensus and communication, the instrument fulfills an important role. In our analysis of other tools, we found that PCPSS $^{46}$ does not include an ethical or death-related domain, nor does it differentiate between the spiritual and psychological/emotional domains that PC-NAT does ${ }^{47,48}$ NATPD- $\mathrm{C}^{49}$ is exclusively used for cancer cases and NAT-PD$\mathrm{HF}^{50}$ for advanced heart disease; $\mathrm{CSNAT}^{51}$ is specifically aimed at caretakers; NA-ACP ${ }^{52}$ and NEST $13^{53}$ test patient response; and, lastly, IDCPAL is focused more on management than clinical practice. ${ }^{54}$ None of the aforementioned tools specifically examines resources and strengths.

\section{Limitations}

These results are a reflection of regular specialized home care and allow us to analyze complexity based on different disease groups. The concept of end-of-life complexity used for this study is based on clinical judgment, which is controversial and awaits consensus. The subjectivity that comes with making such clinical judgments is mitigated to 
some extent by prior training and the entire evaluation team coming to an agreement on complexity levels.

This tool is currently in the process of validation. However, partial validations not yet published in English have been conducted and have demonstrated high interrater reliability (Kappa $=0.92) .{ }^{12}$ Based on these results, the Department of Health of the Government of Catalonia has decided to implement the tool in the management of such patients.

The sample size of neurological and frailty/multimorbidity patients was lower than necessary and might have affected statistical power in these groups. ${ }^{55}$ However, due to the larger size of the other groups, important differences were detected in frailty/multimorbidity patients and the trends observed are plausible.

\section{Generalizations and Perspectives}

The results of our study can be extrapolated to the field in question, or rather, to $\mathrm{AD} / \mathrm{EOL}$ patients treated by specific home care teams, regardless of population differences. ${ }^{56}$

The patterns observed suggest that specialized palliative home care should be focused mainly on cancer, neurology, and organ failure rather than fragility and dementia. Specifically, in the case of patients with cancer or organ failure, quick access to palliative care beds must be available and preferences regarding place of death must be taken into consideration. Our results also show that the role of the social worker on these teams and their integration in the social and community network must be reinforced $^{57-63}$ and that, due to the intensity of this type of care (refractoriness, changing circumstances and short duration), health-care teams and professionals must be encouraged to practice self-care. ${ }^{64-68}$

These findings highlight the importance of the presence of a skilled caregiver in the home, as well as the need for assessment of all areas included in the model due to the heavy burden that the psychosocial field can have on suffering at the end-of-life. ${ }^{45,69}$

We also recommend further analysis of complexity as observed in non-cancer groups, and it will be interesting to see the evolution of complexity. Future research should focus on specific validation studies of this instrument.

\section{Conclusions}

This study sheds light on the high-intensity work of support teams, the importance of the social/family domain and planning the place of death in home care, substantial differences in needs and resources across disease groups, and the importance of relationship wellbeing at the end-of-life.

\section{Abbreviations}

"Organ failure", Advanced chronic organ failure; AD/ EOL, Advanced disease and/or end-of-life; HexCom, Hexagon of Complexity; PADES, Home care support team program.

\section{Consent for Publication}

Not applicable, as the manuscript does not contain personal data.

\section{Data Sharing Statement}

While the IDIAP Jordi Gol does not plan on storing anonymous data in a public database, it will provide access to files should reviewers request it.

\section{Ethics and Consent Statement}

This study was conducted in accordance with the Declaration of Helsinki. This project was assessed by the Clinical Research Ethics Committee (CEIC) of the IDIAP Jordi Gol. Participating patients gave their informed consent. All participants read and signed an informed consent form.

\section{Acknowledgments}

We would like to thank Maria Jesús Micó for her administrative support and Colleen McCarroll for translating and reviewing the English version of this article. We would also like to thank the professionals from the participating PADES teams: Alt-Empordà, Alt-Maresme (Blanes), Bages, BaixCamp, Baix-Litoral (Sant Boi), Baix-Penedès (Vendrell), Cerdanya, Cornellà, Delta-Hospitalet Sud, El Prat De LLobregat (Delta del Llobregat), Garraf (Vilanova i La Geltrú), Geriàtric (Sabadell), Gironés i Pla de l'Estany, Gràcia, Horta Guinardó, Baix Llobregat-Litoral SAP Delta, Les Corts, Mataró, Martorell, Mollet, Nou Barris, Pallars, Pal-liació Cerdanyola, Palliació Sabadell, Pius Hospital de Valls, Pla d'Urgell-Garrigues, Reus, Ripollès, Sant Cugat, Sant Feliu de Llobregat, Sant Martí Nord, Santa Coloma de Gramenet, Santa Susanna Caldes de Montbui, Segrià Sud de Lleida, Selva Marítima (Blanes), Tarragona, Tarragonès, Tortosa, Badalona-Sant Adrià, Igualada-Anoia, Baix EbreMontsià, Dreta Eixample, Sants-Montjuic. We would like to thank the team managers: Anna Serra Plana, Cristina Prat Asensio, Marta Camprubí Rovira, Montse Bonet Martí, J. Cristina Cabrera Bermúdez, Sandra Barceló Castelló, Maica Vallbona González, Lourdes Cortés Bofill, Mercedes 
Liras García, Marta Sierra García, José M. Cantalejo Moreno, Montserrat López Postigo, Montse Parés Feu, Carme Bassedas Ballús, Angela Cadena Andreu, M. Dolors Martí Colomer, Josep M. Picaza Vilà, Santi Bernades Teixidó, Francesc-Xavier Bosch Petit, Alba Feixa Quer, Priscila Muñoz San Juan, Glòria Rovira Oliva, Ramona González Rubió, Manel Esteban Pérez, Montserrat Bonamaison Tena, Carles Gener Turón, Montse Bonilla Martos, Francisco Cordero Higuero, Alex López Català, Anna Torrents Iglesias, M. Núria Arraràs Torrelles, Jéssica Galán Fernández, Gemma Serra Recasens, Marta Blasco Pastor, Cinta Castellà Valldepérez, Núria Miralles Banqué, Anna Vidal Basalo, Sonsoles Frutos Díaz, Enric Martínez Vieites, Aïna Puig Rodríguez.

\section{Author Contributions}

All authors made substantial contributions to conception and design, acquisition of data, and data analysis and interpretation. They took part in drafting the article and revising its content, approved the final version to be published and agreed to be held accountable for all aspects of the work.

\section{Funding}

The IDIAP Jordi Gol funded this project's databases, and the main researcher $(\mathrm{XB})$ received an internal grant from the Metropolitan Nord Primary Care Service (Catalan Health Institute), the objective of which is to promote research strategies in Primary Care by providing exclusive work packages (60 to $120 \mathrm{hrs}$ ) to clinicians to conduct research. This is a public institution that provides logistical and methodological support for research projects without interfering in their design or the collection, analysis and interpretation of data or the drafting of manuscripts.

\section{Disclosure}

The authors report no conflicts of interest in this work.

\section{References}

1. Connor S, Gómez-Batiste X. Assesing the need for palliative care in populations and contexts. In: Gómez-Batiste X, Connor S, editors. Building Integrated Palliative Care Programs and Services. Barcelona; 2017:79-92.

2. Ferris FD, Balfour HM, Bowen K, et al. A model to guide patient and family care: based on nationally accepted principles and norms of practice. J Pain Symptom Manag. 2002;24:106-123. doi:10.1016/ S0885-3924(02)00468-2

3. Ministerio de Sanidad Política Social e Igualdad. Estrategia en Cuidados Paliativos del Sistema Nacional de Salud. Actualización 2010-2014. 2011 1-72. Available from: http://www.msssi.gob.es/orga nizacion/sns/planCalidadSNS/cuidadosPaliativos.htm. Accessed Apr $1,2018$.
4. Codorniu N, Tuca A. Complexity levels of interventions in a hospital support team: descriptive study about prevalence, clinical characteristics and team organisation for each level. In: EAPC Abstrats, editor. 3rd European Association for Palliative Care Research Congress Stresa, Italy 2004. Palliative Medicine;2004; 303-393

5. Tercero-Talavera F. Conceptos básicos para manejar la complejidad. $1^{\text {st }}$ ed. Tercero-Talavera F, editor. Managua. 2016;143-168 p.

6. Normand C. Setting priorities in and for end-of-life care: challenges in the application of economic evaluation. Heal Econ Policy Law. 2012;7:431-439. doi:10.1017/S1744133112000229

7. Marshall D, Myers J. Complexity science and palliative care: drawing from complex adaptive systems theories to guide our successes. J Palliat Med. 2018;21(9):1210-1211. doi:10.1089/jpm.2017.0667

8. Plsek PE, Greenhalgh T. Complexity science: the challenge of complexity in health care. BMJ. 2001;323:625-628.

9. Sturmberg JP, Martin CM. Complexity and health - yesterday's traditions, tomorrow's future. J Eval Clin Pract. 2009;15:543-548. doi:10.1111/j.1365-2753.2009.01163.x

10. Generalitat de Catalunya Departament de Salut. Descripció $i$ Consens dels Criteris de Complexitat Assistencial i Nivells d'intervenció en l'atenció al Final de la vida. Barcelona: Direcció General de Planificació i Avaluació; 2009. Available from: http://canalsalut.gen cat.cat/web/.content/contingut_responsiu/salutAZ/C/cures_paliatives/ documents_prof/treballcomplexi2010.pdf.

11. Esteban-Pérez M, Grau IC, Castells-Trilla G, et al. Complejidad asistencial en la atención al final de la vida: criterios y nivelesde intervención en atención comunitaria de salud. Med Paliat. 2015;22:69-80. doi:10.1016/j.medipa.2013.03.007

12. Esteban-Pérez M, Fernández-Ballart J, Boira-Senlí R, MartínezSerrano T, Nadal-Ventura S, Castells-Trilla G. Concordancia entre la complejidad observada desde diferentes niveles asistenciales en pacientes crónicos complejos, con enfermedad avanzada o al final de la vida mediante un modelo de abordaje de la complejidad. Med Paliat. 2018;25:236-244.

13. Grembowski D, Schaefer J, Johnson KE, et al. Conceptual model of the role of complexity in the care of patients with multiple chronic conditions. Med Care. 2014;52:7-14. doi:10.1097/MLR.0000000000000045

14. Radbruch L, Payne S. White paper on standards and norms for hospice and palliative care in Europe: Part 1. Eur J Palliat Care. 2009;16:278-289.

15. Busquet-Duran X. L'hexàgon de la complexitat (HexCom). Intercanvis/Intercambios Psicoanàlisi. 2017;38:86-106.

16. Puchalski CM, Vitillo R, Hull SKRN. Improving the spiritual dimension of whole person care: reaching national and international consensus. J Palliat Med. 2014;17(6):1-15. doi:10.1089/jpm.2014.9427

17. Benito E, Oliver A, Galiana L, Barreto P, Pascual A, Gomis CBL. Development and validation of a new tool for the assessment and spiritual care of palliative care patients. J Pain Symptom Manag. 2014;47(6):1008-1018. doi:10.1016/j.jpainsymman.2013.06.018

18. Finlay IG, Higginson IJ, Goodwin DM, et al. Palliative care in hospital, hospice, at home: results from a systematic review. Ann Oncol. 2002;13:257-264. doi:10.1093/annonc/mdf668

19. Kimbell B, Murray SA, MacPherson S, Boyd K. Embracing inherent uncertainty in advanced illness. BMJ. 2016;354:1-4.

20. World Health Organization Regional Office for Europe. Palliative care the solid facts. 2004. Available from: https://apps.who.int/iris/ handle/10665/107561. Accessed March 11, 2020.

21. Gómez-Batiste X, Martínez-Muñoz M, Blay C, et al. Prevalence and characteristics of patients with advanced chronic conditions in need of palliative care in the general population: a cross-sectional study. Palliat Med. 2014;28(4):302-311. doi:10.1177/0269216313518266

22. Generalitat de Catalunya. Agència de Qualitat i Avaluació Sanitàries de Catalunya. Central de Resultats, Ambit Sociosanitari, Dades 2016 (OBSERVATORI DEL SISTEMA DE SALUT DE CATALUNYA) [Internet]. Barcelona (Spain); 2016. Available from http://observator isalut.gencat.cat. 
23. Espinosa J, Gomez-Batiste X, Picaza JM, Limon E. Equipos de soporte domiciliario de cuidados paliativos en Espa?. Med Clin (Barc). 2010;135(10):470-475. doi:10.1016/j.medcli.2010.06. 004

24. Alonso-Babarro A, Bruera E, Varela-Cerdeira M, et al. Cant this patient be discharged home? Factors associated with at-home death among patients with cancer. J Clin Oncol. 2011;29:1159-1167. doi:10.1200/JCO.2010.31.6752

25. Doblado R, Herrera E, Librada S, Lucas MÁ, Muñoz I, Rodríguez Z. Análisis y evaluación de los recursos de Cuidados Paliativos de España. Sociedad Española de Cuidados Paliativos. 2016;1-139 p.

26. Woitha K, Garralda E, Martin-Moreno JM, Clark DCC. Ranking of palliative care development in the countries of the european union. J Pain Symptom Manag. 2016;52:370-377. doi:10.1016/j.jpainsymman. 2016.03.008

27. Seidel D, Thyrian JR. Burden of caring for people with dementia comparing family caregivers and professional caregivers A descriptive study. J Multidiscip Healthc. 2019;12:655-663. doi:10. 2147/JMDH.S209106

28. van Schrojenstein Lantman M, Mackus M, Otten L, et al. Mental resilience, perceived immune functioning, and health. $J$ Multidiscip Healthc. 2017;10:107-112. doi:10.2147/JMDH.S130432

29. Martín-Utrilla S, Villasana-Sarabia A, Gallart-Gomez P, ManchenoAlvaro A. Diagnóstico de la complejidad de la atención paliativa en hospitalización a domicilio versus hospitalización convencional Therapeía. 2016;8:31-45.

30. Stiel S, Heckel M, Seifert A, Frauendorf T, Hanke RM, Ostgathe C. Comparison of terminally ill cancer- vs. non-cancer patients in specialized palliative home care in Germany - a single service analysis. BMC Palliat Care. 2015;14(1):34. doi:10.1186/s12904-015-0033-z

31. Aira Ferrer P, Domínguez Lorenzo C, Cano González JM, et al. Características de los pacientes con enfermedad crónica avanzada incluidos en un programa de cuidados paliativos domiciliario. Med Paliat. 2017;24(4):179-187. doi:10.1016/j.medipa.2015.08.001

32. Waller A, Girgis A, Johnson C, et al. Improving outcomes for people with progressive cancer: interrupted time series trial of a needs assessment intervention. $J$ Pain Symptom Manag. 2012;43 (3):569-581. doi:10.1016/j.jpainsymman.2011.04.020

33. Potash M, Breitbart W. Affective disorders in advanced cancer. Hematol Oncol Clin North Am. 2002;16(3):671-700. doi:10.1016/ S0889-8588(02)00013-8

34. Chochinov H, Wilson K, Enns M. Desire for death in the terminally ill. J Psychiatry. 1995;152:1185-1191.

35. Bellido-Pérez M, Monforte-Royo C, Tomás-Sábado J, Porta-Sales J, Balaguer A. Assessment of the wish to hasten death in patients with advanced disease: a systematic review of measurement instruments. Palliat Med. 2016;1:1-16.

36. Naudeillo Cosp M, Fustero AE, Ayma DQ, et al. Análisis del duelo en una muestra de familiares de pacientes ingresados en una unidad de cuidados paliativos. Med Paliat. 2012;19:10-16. doi:10.1016/j. medipa.2010.11.007

37. Blanco Toro L, Librada Flores S, Rocafort Gil J, Cabo Domínguez R, Galea Marín T, Alonso Prado ME. Perfil del cuidador principal del enfermo en situación terminal y análisis del riesgo de desarrollar duelo patológico. Med Paliat. 2007;14:164-168.

38. Vicent L, Nuñez Olarte JM, Puente-Maestu L, et al. Degree of dyspnoea at admission and discharge in patients with heart failure and respiratory diseases. BMC Palliat Care. 2017;16:35. doi:10.1186/ s12904-017-0208-x

39. Veronese S. The challenges of palliative care for those with neurological diseases. Palliat Med. 2018;32:706-707. doi:10.1177/0269216 318760767

40. Hogden A, Foley G, Henderson R, James N, Aoun S. Amyotrophic lateral sclerosis: improving care with a multidisciplinary approach. J Multidiscip Healthc. 2017;10:205-215. doi:10.2147/JMDH.S134 992
41. Fox S, FitzGerald C, Harrison Dening K, et al. Better palliative care for people with a dementia: summary of interdisciplinary workshop highlighting current gaps and recommendations for future research. BMC Palliat Care. 2018;17:9. doi:10.1186/ s12904-017-0221-0

42. Emanuel L, Powell RA, Handzo G, Michelson KN, Dhingra L. Validated assessment tools for psychological, spiritual, and family isues. In: Cherny N, M F, S K, RK P, DC C, editors. Oxford Textbook of Palliative Medicine. $5^{\text {th }}$ ed. Oxford University Press; 2015:398405.

43. Kupeli N, Leavey G, Moore K, et al. Context, mechanisms and outcomes in end of life care for people with advanced dementia. BMC Palliat Care. 2016;15:31. doi:10.1186/s12904-016-0103-x

44. Esteban-Pérez M, Fernández-Ballart J, Boira-Senlí RM, MartínezSerrano T, Nadal-Ventura SC-TG. Concordancia entre la complejidad observada desde diferentes niveles asistenciales en pacientes crónicos complejos, con enfermedad avanzada o al final de la vida mediante un modelo de abordaje de la complejidad. Med Paliat. 2018;25 (4):236-244. doi:10.1016/j.medipa.2017.05.008.

45. Ventura AD, Burney S, Brooker J, Fletcher J, Ricciardelli L. Homebased palliative care: a systematic literature review of the self-reported unmet needs of patients and carers. Palliat Med. 2014; 28:391-402. doi:10.1177/0269216313511141

46. Girgis A, Waller A. Palliative care needs assessment tools. In: Cherny N, Fallon M, Kaasa S, Russell K, Portenoy and DCC, editors. Oxford Textbook of Palliative Medicine. $5^{\text {th }}$ ed. Oxford University Press; 2015:363-375.

47. Waller A, Girgis A, Currow D, Lecathelinais C. Development of the palliative care needs assessment tool (PC-NAT) for use by multi-disciplinary health professionals. Palliat Med. 2008;22(8):95 6-964. doi:10.1177/0269216308098797

48. Masso M, Allingham SF, Johnson CE, et al. Palliative care problem severity score: reliability and acceptability in a national study_XXX. Palliat Med.2016;30(5):479-485. doi:10.1177/026921 6315613904

49. Waller A, Girgis A, Lecathelinais C, et al. Validity, reliability and clinical feasibility of a needs assessment tool for people with progressive cancer. Psychooncology. 2010;733:726-733.

50. Waller A, Girgis A, Davidson PM, et al. Facilitating needs-based support and palliative care for people with chronic heart failure: preliminary evidence for the acceptability, inter-rater reliability, and validity of a needs assessment tool. J Pain Symptom Manag. 2013;45:912-925. doi:10.1016/j.jpainsymman.2012.05.009

51. Ewing G, Brundle C, Payne S, Grande G. The Carer Support Needs Assessment Tool (CSNAT) for use in palliative and end-of-life care at home: a validation study. J Pain Symptom Manage. 2013;46:39 5-405. doi:10.1016/j.jpainsymman.2012.09.008

52. Rainbird KJ, Perkins JJ. The needs assessment for advanced cancer Patients (Na-Acp): a measure of the perceived needs of patients with advanced, incurable cancer. a study of validity, reliability and acceptability. Psychooncology. 2005;306:297-306. doi:10.1002/pon. 845

53. Scandrett KG, Reitschuler-Cross EB, Nelson L, et al. Feasibility and effectiveness of the NEST13+ as a screening tool for advanced illness care needs. J Palliat Med. 2010;13:161-169. doi:10.1089/jpm.2009. 0170

54. Salvador Comino R, Garrido Torres N, Perea Cejudo I, Martin Rosello ML, Regife Garcia V, Fernandez Lopez A. El valor del instrumento diagnostico de la complejidad en cuidados paliativos para identificar la complejidad en pacientes tributarios de cuidados paliativos. Med Paliat. 2017;24:196-203. doi:10.1016/j.medipa.2016. 01.003

55. Sørbye LW, Sverdrup S, Pay BB. Should frail older adults be in long-term care facilities? J Multidiscip Healthc. 2018;11:99-107. doi:10.2147/JMDH.S155372 
56. Nabal M, Barcons M, Moreno R, et al. Patients attended by palliative care teams: are they always comparable populations? Springerplus. 2013;2:177. doi:10.1186/2193-1801-2-177

57. Thomsen KT, Guldin M-B, Nielsen MK, Ollars CL, Jensen AB. A process evaluation of systematic risk and needs assessment for caregivers in specialised palliative care. BMC Palliat Care. 2017;16:23. doi:10.1186/s12904-017-0196-x

58. Weibull A, Olesen F, Neergaard MA. Caregivers' active role in palliative home care - to encourage or to dissuade? A qualitative descriptive study. BMC Palliat Care. 2008;7:15. doi:10.1186/1472-684X-7-15

59. Wang C-W, Chan CLW, Chow AYM. Social workers' involvement in advance care planning: a systematic narrative review. BMC Palliat Care. 2018;17(1):5. doi:10.1186/s12904-017-0218-8

60. Payne S, Eastham R, Hughes S, Varey S, Hasselaar J, Preston N. Enhancing integrated palliative care: what models are appropriate? A cross-case analysis. BMC Palliat Care. 2017;16.

61. Payne S. White paper on improving support for family carers in palliative care: part 1. Eur J Palliat Care. 2010;17:238-245.

62. Sociedad Española de Cuidados Paliativos. Monografías SECPAL. Trabajo social en cuidados paliativos. 2015. $171 \mathrm{p}$.

63. Sandsdalen T, Wilde-Larsson B, Grøndahl VA. Patients' perceptions of the quality of palliative care and satisfaction - a cluster analysis. $J$ Multidiscip Healthc. 2019;12:903-915. doi:10.2147/JMDH.S22 0656
64. Bayes R. Necesidad y uso del método poético en el ámbito sanitario. Rev Iberoam Psicosomática. 2017;121.

65. Pask S, Pinto C, Bristowe K, et al. A framework for complexity in palliative care: a qualitative study with patients, family carers and professionals. Palliat Med. 2018;026921631875762.

66. Orellana-Rios CL, Radbruch L, Kern M, et al. Mindfulness and compassion-oriented practices at work reduce distress and enhance self-care of palliative care teams: a mixed-method evaluation of an "on the job" program. BMC Palliat Care. 2018;17:3. doi:10.1186/ s12904-017-0219-7

67. Benito Oliver E, De Albornoz PAC, López HC. Herramientas para el autocuidado del profesional que atiende a personas que sufren. FMC Form Medica Contin en Aten Primaria. 2011;18(2):59-65. doi:10.10 16/S1134-2072(11)70023-8

68. Los Morandi T. PADES: red de vida. Med Paliat. 2018;25(2):11 4-115. doi:10.1016/j.medipa.2016.10.005

69. Costa V, Earle CC, Esplen MJ, et al. The determinants of home and nursing home death: a systematic review and meta-analysis. $B M C$ Palliat Care. 2016;15(1):8.
Journal of Multidisciplinary Healthcare

\section{Publish your work in this journal}

The Journal of Multidisciplinary Healthcare is an international, peerreviewed open-access journal that aims to represent and publish research in healthcare areas delivered by practitioners of different disciplines. This includes studies and reviews conducted by multidisciplinary teams as well as research which evaluates the results or conduct of such teams or healthcare processes in general. The journal
Dovepress

covers a very wide range of areas and welcomes submissions from practitioners at all levels, from all over the world. The manuscript management system is completely online and includes a very quick and fair peer-review system. Visit http://www.dovepress.com/testimonials. php to read real quotes from published authors. 